\title{
Research and Practice of Promoting the Professional Cultivating Ability in Higher Vocational Colleges by Ternary Construction
}

\author{
Chen Gangtian
}

\begin{abstract}
Training of professional ability is an important attribute of vocational education, and professional training ability is a key factor to realize this attribute. Professional training ability is contributed by many factors including school running entities, practical training conditions, teaching staff, curriculum system, teaching reform, etc. It has been proved by practice that it is difficult to realize the upgrading of vocational training ability through the construction of the colleges themselves. The higher vocational colleges should seek the support of local government to attract and introduce deep participation of excellent enterprises and educational institutes into the whole education process, in order to upgrade their professional training ability and quality and lay solid foundation for their students' vocational development through institutional and mechanism innovations.
\end{abstract}

Index Terms - Ternary construction, professional training ability, vocational ability training, cooperation in running schools.

\section{THE INNOVATIVE ENVIRONMENT FOR DOMESTIC HIGHER VOCATIONAL COLLEGES SCHOOL-RUNNING SYSTEM AND MECHANISM IS GETTING BETTER}

After nearly 20 years of development, higher vocational education in China, especially promoted by construction of national demonstration (key) higher vocational colleges, has greatly improved the conditions and connotation of schooling, but at the same time, is accompanied by a series of underlying problems. The reform has gradually entered a deep-water zone of school-running system and mechanism. Practice has proved that the public or private school-running pattern of higher vocational colleges in the past was difficult to innovate school-running system and mechanism, and the vitality of schooling could not be released. The conflict between school personnel training and social needs is still very prominent [1].

In May 2014, the "Decision of the State Council on Accelerating the Development of Modern Vocational Education" clearly stated that "exploring the development of joint-stock system and mixed-ownership vocational colleges, and exploring the mechanism of mutual mandatory administration and purchasing services by public institutions run by public and social forces". In October of the following year, the Ministry of Education issued the "Action Plan for the Innovation and Development of Higher Vocational

Manuscript received on May 18, 2018; revised December 23, 2018. This work was supported in part by Dongying Vocational Institute.

Chen Gangtian is with Dongying Vocational Institute, Dongying, Shandong, China (e-mail: zsmcgt@163.om).
Education (2015-2018)", which regards "giving play to the main role of enterprises in running schools, and exploring the development of higher vocational colleges with joint-stock system and mixed ownership" as the basic principle. In April 2018, the General Office of the State Council issued the "Several Opinions on Deepening the Integration of Production and Education", taking "gradually increasing the involvement of industries and enterprises in running schools, improving a diversified school-running system, and fully implementing school-enterprise cooperation for higher vocational education" as the main goals. It can be seen that the state's views on the participation of social forces in vocational education are very clear. Vocational institutions are encouraged to explore the model of cooperative education. Vocational colleges join hands with enterprises and introduce educational institutions, and multi-subject school-running will become the future development trend of vocational education.

\section{Professional Training Ability OF Higher VACATIONAL COLLEGES HaS A LONG WAY TO Go}

Higher vocational education has the attribute of vocational ability training. The participation of enterprises in the training process is a key factor to realize this attribute. Practice has proved that it is difficult for social forces to participate in the whole process of training students in higher vocational colleges simply by providing internships or by simply purchasing services from educational and training institutions.

Because enterprises only act as employers, and do not have the motivation to participate in the education process, making the "co-running school with the enterprise" stagnant in a long time. Professional education and training institutions were born at the right moment, providing another feasible exit for the breakthrough of this dilemma. Educational institutions are driven by interest to participate in the education process. If combining with the employment needs of enterprises, they can form a social force to participate in the complete chain of education. Therefore, it is of great practical significance to explore the Ternary cooperation training model for vocational colleges, enterprises, and education and training institutions.

\section{A. Cooperation in Running Schools among Enterprises, Colleges and Training Institutions}

Professional training ability is the key to guarantee the quality of personnel training of vocational education. Implementing cooperation in running schools among 
enterprises, colleges and training institutions is the core issue of improving professional training ability. Although the environment of mixed ownership operation in running schools has become increasingly loosened, the current mixed ownership problem still needs to be broken through in practice. The diversified management structure is still difficult to form, and the school-enterprise integration is still at a superficial level, which makes it difficult to achieve success in quality improvement of professional training ability. [2]

Higher vocational colleges should conduct in-depth research on the implementation of existing policies, actively seek the support of governments and industry associations, take institutional innovation as a prerequisite, take multi-win conditions as the tie, and use vocational ability training as the main line for the purposes of quality employment. Real innovation should be made to stimulate the endogenous power of cooperation between enterprises and schools, and high-quality resources in society should be gathered to establish cooperative relationship among colleges, enterprises and education institutions in running schools. A variety of methods such as government purchases and enterprises paying service fees should be adopted, and innovative cooperation models with education and training institutions should be explored to establish a dynamic and long-acting cooperation mechanism, and exert the role of the vocational education attributes of vocational colleges. Currently, the prototype of this model has appeared in higher vocational colleges.

\section{B. Practical Training Base of Ternary Construction}

The construction of practical training conditions of higher vocational colleges is an important part of the Ternary construction. Based on sharing and win-win, and the principle of high efficiency, practicality and appropriate advance, a sharing training base for learning, production and research should be built on campus [3]. Higher vocational colleges should win over project funds, build basic practical training facilities, purchase basic training equipment, and form basic training conditions; encourage employers to invest or donate production equipment for production training and social work with measures such as preferential use of human rights; introduce education and training institutions by government procurement of services, focusing on investment of new equipment, new technologies, new processes, and flexible equipment for high-level skills training and social service use.

Cooperation and co-construction are not simply repeated investment by all parties involved. They must cooperate according to their respective roles and at the same time ensure the participation and right to know of all parties in order to maximize the rights and interests of all parties and form a long-term mechanism for training base construction. Through the design of the system, it is possible to avoid the phenomenon of all parties acting negligently and mutually making excuses as well as a vicious circle of nobody's jurisdiction. Any idea or practice that hopes or depends on one side may push cooperation to the opposite side, once the cooperation enters into an unsustainable situation, the school and the students will ultimately bear the loss.

\section{Ternary Construction of Teaching Team of Double Professionally-Titled Teachers}

At present, the public higher vocational colleges still lack the autonomy of faculty recruitment, and long-term pursuit of highly educated teachers has led to the irrational faculty structure and insufficient number of full-time teachers. The proportion of teachers and students who are barely up to standard has all scraped together. The quality indicators of dual-professional teachers are even more formalistic and have not been fundamentally resolved. The employment of part-time teachers is also difficult. The majority of qualified and capable part-time teachers are the backbone of enterprises and institutions, so they have little time and energy to give consideration to teaching work and even the teaching time is difficult to guarantee, and it is even more difficult for them to participate in the professional building of colleges. Therefore, it is difficult to fundamentally improve the faculty structure and training ability. [4]

School-enterprise cooperation can solve the problem of difficult employment of some full-time and part-time teachers. However, for comprehensive higher vocational colleges, because there are many majors and industries, it is difficult for factories in colleges to cover most majors, which involves the issue of specialized development and comprehensive development in the higher vocational education, so it is not discussed here. The education and training institutions have the advantages of appointment and management of full-time practical training teachers, so they can cover the shortage of the number and structure full-time teachers in colleges to a certain extent, and can purchase high-quality teacher resources through government purchase services. Adopting a combination of factories-in-colleges and agency appointment is conducive to the construction of higher vocational colleges' dual-faculty teaching teams and can effectively alleviate the insufficiency of teachers' training and teaching ability.

\section{Entire-Process Co-cultivation Curriculum System of School-Enterprise-Training Construction}

The Entire-process co-cultivation curriculum system by alternately implementing on-campus learning and training off-campus practice should be established by making use of the superiority of the school-enterprise-training teaching team to jointly study and formulate professional development plans, jointly develop personnel training programs, jointly compile teaching materials for work and study, and jointly plan industrial and corporate cognition, industry market research, post cognition, and post-training internships. [3]

The school-enterprise-training teaching team is the foundation for building a vocational training-based curriculum system. It is easier for the multi-structured team to understand and respect the production rules of enterprises. On this basis, schools should establish a practical teaching support mechanism, fully authorize various basic academic institutions, and ensure the organization and implementation of practical teaching in the curriculum system. This is one of the key links in the development of professional competence and quality.

\section{E. Teaching Reform Should Focus on Practical Results and Long-Term Planning}


The educational reform of higher vocational colleges has a long way to go. It must first be differentiated by the characteristics of majors, the nature of the curriculum, etc., and be constrained by many conditions such as the content of the teaching materials, the number of teachers, the ability of the dual-faculty, and the training equipment. Although traditional theoretical teaching cannot meet the requirements of vocational ability training, blindly pursuing the so-called "learning and practice" and "learning by doing" is easy to be divorced from reality. It is inevitable that the teaching reform will evolve into a sport-style "toss" and disrupt the normal teaching order, increasing the extra burden on teachers, impairing teachers' enthusiasm for work, and even leading to a deviation from the "higher learning" attributes of higher vocational education.

Of course, under the premise that conditions are in place or can be created, it is necessary to promote the reform of integration of theory and practice. Some colleges and universities have proved that the teaching mode of "one lesson, two teachers" (a full-time teacher with a corporate training teacher) is a feasible teaching reform method, which can not only improve the quality of teaching, but also improve practical teaching ability for full-time teachers. In recent years, the vocational education alliance or group born at the right moment should play its due role, establish inter-school and inter-enterprise training mechanisms in rotation for young and middle-aged teachers, and encourage young teachers to do social practice in colleges and industrial enterprises so as to improve their practical training and practical teaching ability. The ability to acquire and use equipment is beneficial to the precise configuration of equipment and facilities in the training base, therefore, teaching reforms will naturally follow.

\section{F. School-Enterprise-Training Platform Supports}

Continuous Enhancement of Professional Training Ability

A Ternary cooperation development platform for vocational colleges, enterprises, and education and training institutions should be established to form a long-term cooperation mechanism for talent cultivation with genuine dual-teacher team and training conditions for the integration of academic, production, and research. Talent training programs and curriculum systems that are in line with the industry should be developed. On-campus production and training factories should be started, and the integrated teaching of theory and practice should be implemented to put the dual-mentor system of internship and professional quality training in practice. As a result, the major training and social service capabilities must be strengthened, students' major-related and stable employment rate will increase accordingly, professional brand awareness will be enhanced in the industry, and the overall strength of the college increases.

\section{INNOVATION IS THE KEY TO BREAKING THROUGH BARRIERS}

A. Dual-Channel to Solve the Problem of Low Enthusiasm for the Participation of Employers in the Personnel Training Process
Enterprises are demanding benefit and efficiency. This requires that vocational education must comply with market demands, establish a flexible and rapid response mechanism, constantly seek and adjust the integrating points with enterprises, and stimulate the enthusiasm of employers and social forces to participate in personnel training. In addition, the education and training institutions participate in the talent development process by means of government purchase of services is an effective transitional measure. When employers have the intention to participate in the training process, the dual cooperation of schools and enterprises will be on the track.

\section{B. Efficiently Use Resources to Solve the Problem of Insufficient Investment in Vocational Education Hardware}

A Ternary construction sharing mechanism for theory teaching, practical training, production and research should be set up. Through joint planning, joint construction, and joint operation by all parties, the integration center for theory teaching, practical training, production and research will give full play to the functions of theory teaching, practical training, production, and research. While theory teaching, practical training, it will provide production and intellectual services to the society, revitalize all hardware and software resources, while exploring the feasibility of using service revenue to compensate enterprises and institutions investment, relieve the pressure of school engagement and tuition increase.

\section{Multi-dimensional Cooperation to Solve the Problem of Superficial Ability of Double Professionally-Titled Teachers}

The school-enterprise-practical training and theory teaching team works together, co-educates, and educates people together, truly forming a "dual-teacher" education mechanism. The dual-faculty team structure is naturally formed, and the environment of complementary and mutual learning can promote the theory teaching competence of full-time teachers gradually. The educational reform of integration of theory and practice will succeed, and the long-term mechanism for the training of teachers will be naturally established.

\section{Complying with the Law of Production and Teaching to Resolve Conflicts between Post Internship and Enterprise Production}

School-enterprise-training institution cooperation has the advantage of understanding the production rules of enterprises. When formulating talent training programs, it can establish corresponding training orientation according to job positions, flexibly arrange the alternate implementation of teaching process inside and outside schools, evade conflict between student internships and enterprise production, and improve the degree of integration between higher vocational colleges and employers. [5]

\section{E. Horizontal Alliance Is a Promoter to the Advancement of Training Ability and Extension of Achievements}

Chain education and training institutions have the advantage of horizontal integration, which makes it easier to achieve resource sharing and promotion of results. However, such advantage is limited to cooperative colleges or majors, 
and it is more difficult to obtain school-level attention. The vocational education group has advantages over administration and industry, but its role has not yet been fully played. Therefore, by exploring and establishing school-enterprise mixed-ownership independent school-running entities, establishing the dominant position of all parties, and gaining the right to speak in private education, the achievements can be rewarded with respect and promotion.

\section{CONCLUSIONS}

In recent years, China state owned higher vocational colleges tried every ways on "co-running school with the enterprises" and gained plenty of experience and achievements, which has been serving in the development of regional economy, the society and culture. But this mode has no substantive break-through on institutions and mechanisms innovation. So, more actively seeking government support and being in line with the development rules of enterprises will surely become the development trend of the higher vocational colleges. So the higher vocational colleges have to create innovative institutions and mechanisms in an open manner, make effort on exploring cooperation and communication among entities of different ownership, introduce the participation of excellent enterprises into education, at the same time, take the advantage of their expertise as educational institutes to form the Ternary cooperative school running mode to create new education platform, in order to upgrade their professional training ability to train more excellent talents and win a broader space for development of themselves.

\section{REFERENCES}

[1] S. Qiang, "Path of mixed ownership reforms of higher vocational colleges," Truths and Facts (Modern Management), vol. 07, 2017.
[2] L. T. Chen, "The dilemma, route and modern governance of the reform of mixed-ownership school-running in vocational colleges," China Higher Education Research, vol. 01, 2017.

[3] G. T. Chen, "School-enterprise cooperation model creates an ideal platform for students' high-quality employment," Enterprise Research, vol. 05, 2012.

[4] G. T. Chen, "Professional co-construction of "order training" promotes integration and win-win outcomes of higher vocational colleges and enterprises," Value Engineering, vol. 06, 2013.

[5] Y. J. Cai, "School-enterprise-training cooperation model of internship of higher vocational colleges," Journal of Kaifeng Institute of Education, vol. 01, 2015.

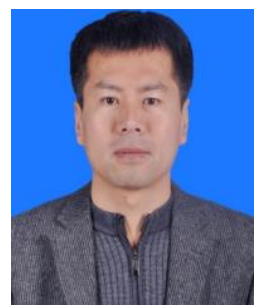

Chen Gangtian was born on August 16, 1969 in Kenli County, Dongying city, Shandong province, China. In 1992, he graduated from Shandong University of Engineering, majoring in automobile and tractor (now known as Shandong University of Technology, major in vehicle engineering), obtained a master's degree in engineering. In 2002, he obtained a master's degree in mechanical engineering from Shanghai Jiaotong University. His research field is gas engine turbocharging technology.

From 1992 to 2003, He worked at the Shengli Petroleum Administration Power Machinery Factory, and served as the director of the design office of the Internal Combustion Engine Research Institute. From 2003 to 2007, he worked for a number of private enterprises in Beijing as a technical management. Since 2008, he has been teaching at Dongying Vocational College, and is the director of the automotive teaching and research office and a major leader. The "Automobile Insurance Claims Practice" and "Automotive Culture and Introduction" edited by him were published by Harbin Institute of Technology Press in June 2018; and his paper "Professional Co-creation Order Training Promotes Higher Vocational Colleges and Enterprises to Communicate and Win Together" was published in the Journal of Value Engineering in June 2013. He is researching on school-enterprise cooperation and judicial appraisal of traffic accidents.

Associate Professor Chen Gangtian is a member of SAE-China, member of Shandong Automobile Maintenance and Inspection Industry Association Vocational Education Branch, member of Shandong Provincial Transportation Industry Steering Committee Road Traffic Branch, Road Traffic Judicial Appraiser, senior examiner of professional technical ability appraisal in China's automobile marketing and aftermarket industry, and senior appraiser of used car appraisal. He has won the Shandong Provincial Patent Innovation Award, the first and second prize of the Science and Technology Progress Award of Shengli Petroleum Administration Bureau, the first prize of Excellent Paper in Science and Technology of Dongying City, and the third prize of Award for Excellence in the Social Sciences in Dongying City. 